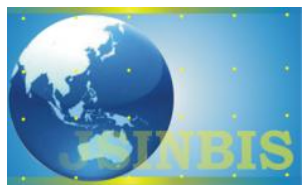

\title{
Pengembangan Sistem Informasi Untuk Menentukan Prioritas Pemberian Kredit dengan Metode Promethee
}

\author{
Sujarwo* \\ Universitas Pesantren Darul Ulum \\ Jombang, Jawa Timur
}

Naskah Diterima : 17 Maret 2015; Diterima Publikasi : 23 April 2015

\begin{abstract}
This study develops an information system for decision-making on priority lending and introduce new information into the decision-making process resulting in the selection process more realistic.The method used in this research method PROMETHEE "Preference Ranking Organization Method for Enrichment Evaluation" is used in a decision support system for its simplicity, clarity, and stability with the assessment of several alternative criteria for determining the order of decision making (priority) in the multicriteria analysis. After that, compared with the manual calculation of the bank. This method can be applied to all types of decision-making problems with heterogeneous information and multigranular. The result of this study is that the information system built to produce a ranking as follows: A prospective customers rank 1, C rank 2, B rank 3, E rank 4, D rank 5, and F rank 6, then compared that with the manual there is a difference ranking ranking which puts prospective customers in rank $\mathrm{F} 4$ which turns the loan installment payments problems occur.
\end{abstract}

Keywords: Promethee; Rank; Decision Making System.

\begin{abstract}
Abstrak
Penelitian ini mengembangkan sebuah sistem informasi untuk pengambilan keputusan pada prioritas pemberian kredit dan memperkenalkan Informasi baru ke dalam proses pengambilan keputusan yang dihasilkan dalam proses seleksi lebih realistis. Metode yang digunakan dalam penelitian ini metode PROMETHEE "Preference Ranking Organization Method for Enrichment Evaluation" digunakan dalam Sistem Pendukung keputusan karena kesederhanaan, kejelasan, dan kestabilan dengan melakukan penilaian dari beberapa alternatif kriteria penilaian pengambilan keputusan untuk penentuan urutan (prioritas) dalam analisis multikriteria. Setelah itu dibandingkan dengan perhitungan manual dari pihak bank. Metode ini dapat diterapkan untuk semua jenis pengambilan keputusan masalah dengan informasi heterogen dan multigranular. Hasil penelitian ini adalah Sistem informasi yang dibangun menghasilkan perankingan sebagai berikut : calon nasabah A ranking 1, C ranking 2, B ranking 3, E ranking 4, D ranking 5, dan $\mathrm{F}$ ranking 6, maka bila dibandingkan yang dengan perankingan manual terjadi perbedaan ranking yang menempatkan calon nasabah $\mathrm{F}$ di ranking 4 yang ternyata dalam pembayaran angsuran kredit terjadi masalah.
\end{abstract}

Kata kunci : Promethee; Perankingan; Sistem Pengambilan Keputusan

\section{Pendahuluan}

Dunia industri baik jasa maupun manufaktur saat ini menghadapi banyak permasalahan dalam mengambil sebuah keputusan. Maka dari itu mereka membutuhkan sebuah sistem informasi pendukung keputusan dengan metode yang dapat menyelesaikan suatu masalah. Apalagi yang berdasarkan pada kriteria yang bervariasi, salah satu metode penentuannya "Multi Criteria Desicion Making" (MCDM) menggunakan metode PROMETHEE. PROMETHEE "Preference Ranking Organization Method for Enrichment Evaluation" digunakan dalam Sistem Pendukung keputusan karena kesederhanaan, kejelasan, dan kestabilan dengan *) Penulis korespondensi: jarwo301@ gmail.com melakukan penilaian dari beberapa alternatif kriteria penilaian pengambilan keputusan untuk penentuan urutan (prioritas) dalam analisis multikriteria, seperti halnya pada pemberian kredit dalam suatu bank maupun perusahaan jasa keuangan. Metodologi Promethee benar-benar mampu untuk menyelesaikan masalah seleksi pilihan karena prosedur yang sederhana dan fleksibel (Halouni, 2007).

Penelitian mengambil studi kasus di Bank Perkreditan Rakyat Baitul Mal Darusalam (BMD) Syariah yang berkantor pusat di jl. Raya Ponorogo No. 87 Dolopo Kabupaten Madiun. Sebagai lembaga keuangan Bank itu tidak hanya menerima simpanan dalam bentuk deposito berjangka, tabungan, namun BPR BMD Syariah juga memberikan kredit usaha 
untuk masyarakat dalam meningkatkan usahanya, baik usaha yang berskala kecil, menengah atau besar. Kredit disini berarti bahwa BPR (BMD) Syariah meminjamkan sejumlah dana kepada nasabah, sedangkan nasabah memiliki tanggung jawab mengembalikan dana tersebut sesuai dengan jangka waktu yang disepakati sesuai dengan perjanjian disertai membayarkan sejumlah keuntungan atau bagi hasil untuk pihak Bank. Maka dari itu Bank Perkreditan Rakyat BMD Syariah perlu meminimalisasi masalah - masalah dan resiko yang terjadi sebelum memberikan kucuran dana kepada para nasabahnya, terutama berkaitan dengan keseimbangan neraca Bank.

Metode PROMETHEE mampu mengintegrasikan dalam prosedur baik data kuantitatif maupun kualitatif dalam konteks pasti. Metode ini dapat diterapkan untuk semua jenis pengambilan keputusan masalah dengan informasi heterogen dan multigranular. Oleh karena itu, penerapan metode ini untuk masalah nyata akan mengarah pada hasil yang lebih baik. Adanya aplikasi ini diharapkan dapat membantu pengambil keputusan dalam menentukan calon nasabah yang tepat untuk diberi kucuran dana kredit serta menyediakan informasi pemberian kredit yang tepat. Tujuan penelitian ini untuk menghasilkan sistem aplikasi yang mampu menentukan prioritas pemberian kredit dengan metode PROMETHEE. Yang harapannya menghasilkan usulan perbaikan prosedur prioritas pemberian kredit.

\section{Kerangka Teori}

\subsection{Metode PROMETHEE}

Metode PROMETHEE telah banyak digunakan oleh para peneliti untuk menyeleksi atau memilih beberapa alternatif dan kriteria karena metode ini dapat diterapkan untuk semua jenis pengambilan keputusan dengan informasi yang heterogen serta lebih mudah membuat pemodelan untuk pengambilan keputusan ini sesuai dengan preferensi pengambilan keputusan pembuat. Diantaranya digunakan untuk pemilihan distribusi statistik terbaik dari tiga metode yang dilakukan oleh Alessio (2011). Selama proses pengambilan keputusan dan interaksinya dengan analisa, bahwa struktur masalah akan menjadi jelas. Model ini bersama-sama dibangun harus menjadi alat untuk mencari, mengeksplorasi, menafsirkan, perbedaan pendapat dari permasalahan (Roy, 2009; Tsoukiàs, 2008). Beberapa set parameter dapat diterima atau diselidiki dalam rangka untuk mengevaluasi dampak masing-masing pada keputusan yang dihasilkan. Penelitian ini menawarkan kepada para pembuat keputusan aplikasi sederhana dan lebih luas dari metode multikriteria Promethee tanpa mengorbankan salah satu yang menguntungkan dan dengan memperhatikan ketidakakuratan data. Sebuah simulasi numerik dari metode yang diusulkan dilakukan untuk menunjukkan kemungkinan-kemungkinannya (Halouani, 2007).

Metode PROMETHEE juga digunakan untuk pengambilan keputusan perdagangan saham. Dalam rangka untuk memilih Saham unggulan (alternatif) untuk investasi, harus mempertimbangkan beberapa alternatif yang kadang-kadang bertentangan kriteria. Oleh karena itu, kita dihadapkan dengan masalah multikriteria pengambilan keputusan yang khusus. Hasil penerapan model ini sebagian besar tergantung pada strategi investasi investor. Investor harus menentukan Fungsi preferensi masing-masing kriteria. Pemilihan industri unggul dan perusahaan unggul mungkin berbeda sesuai dengan strategi diterapkan oleh masing-masing individu. Dalam model ini, ketentuan yang mengatur stok pasar seperti situasi kondisi politik dan pasar tidak dipertimbangkan. Kasus teknis analisis ini juga akan membantu dalam menentukan waktu yang tepat untuk membeli atau menjual saham (Amir Albadvi, 2006).

Semua parameter alternatif dan kreteria yang dinyatakan mempunyai pengaruh nyata menurut pandangan ekonomi (Hu dan Chiung, 2011) dan data dasar untuk evaluasi dengan methode PROMETHEE disajikan pada Tabel 1 sebagai berikut.

Tabel 1. Tabel metode PROMETHEE

$\begin{array}{llllll}f l(.) & f 2(.) & \ldots . . & f j(.) & . . & f k(.)\end{array}$

a1

a2

fj(ai)

$\cdots$

Dimana a1, a2, .... an adalah alternatif alternatif yang di syaratkan dan $f 1, f 2, \ldots . . f k$ adalah kreteria dari masing - masing alternatif.

PROMETHEE adalah metode pengambilan keputusan multikriteria dikembangkan oleh Brans et al. (1996). Ia membandingkan setiap pasangan alternatif untuk setiap kriteria dan nilai alternatif dalam 0 - 1 interval. Nilai $f$ merupakan nilai nyata dari suatu kriteria dan tujuannya berupa prosedur optimasi untuk setiap alternatif yang akan diseleksi a adalah $f(a)$ merupakan evaluasi dari alternatif yang akan diseleksi tersebut untuk setiap kriteria. Penyampaian Intensitas dari preferensi ( pilihan) alternatif a terhadap alternatif $b$ sedemikian rupa sehingga:

- $\quad \mathrm{P}(\mathrm{a}, \mathrm{b})=0$, berarti tidak ada beda antara a dan b, atau tidak ada preferensi dari a lebih baik dari b.

- $\mathrm{P}(\mathrm{a}, \mathrm{b}) \approx 0$, berarti lemah preferensi dari a lebih baik dari b.

- $\quad \mathrm{P}(\mathrm{a}, \mathrm{b})=1$, kuat preferensi dari a lebih baik dari b.

- $\mathrm{P}(\mathrm{a}, \mathrm{b}) \approx 1$, berarti mutlak preferensi dari a lebih baik dari $b$. 
Setiap kriteria boleh memiliki nilai dominasi kriteria atau bobot kriteria yang sama atau berbeda, dan nilai bobot tersebut harus di atas 0 (Yilmaz et al., 2011). Sebelum menghitung bobot untuk masing-masing kriteria, maka dihitung total bobot dari seluruh kriteria terlebih dahulu. Berikut rumus 2.1 untuk perhitungan bobot kriteria :

$$
\begin{gathered}
W_{j}=\frac{W_{i}}{\Sigma W_{i}} \\
\sum W_{j}=1
\end{gathered}
$$

ket : $\mathrm{W}_{\mathrm{j}}=$ Pembobotan

$\mathrm{W}_{\mathrm{n}}=$ jumlah bobot tiap kriteria

$\sum \mathrm{W}_{\mathrm{n}}=$ jumlah total semua kriteria

Rumus perbandingan untuk setiap alternatif, sebagai berikut :

$$
\pi\left(a_{1}, a_{i}\right)=\sum_{j-1}^{j} W_{j} \times P_{j}\left(a_{1}, a_{i}\right)
$$

Ket : $\pi=$ nilai perbandingan tiap alternatif

$$
\begin{aligned}
& \mathrm{a}_{1}=\text { alternatif } 1 \\
& \mathrm{a}_{\mathrm{i}}=\text { alternatif } \mathrm{ke}-\mathrm{n} \\
& \mathrm{P}_{\mathrm{j}}=\text { perbandingan dengan kriteria }
\end{aligned}
$$

Perangkingan yang digunakan dalam metode PROMETHEE meliputi tiga bentuk antara lain :

a. Entering flow

Entering flow adalah jumlah dari yang memiliki arah mendekat dari titik a dan hal ini merupakan karakter pengukuran outrangking. Untuk setiap nilai a dalam grafik nilai outrangking ditentukan berdasarkan entering flow dengan persamaan:

$$
\emptyset^{+}(a)=\frac{1}{n-1} \sum_{x \in a} p(a, x)
$$

$$
\begin{aligned}
& \mathrm{n}=\text { jumlah alternatif } \\
& \mathrm{p}(\mathrm{a}, \mathrm{x})=\text { preferensi a terhadap } \mathrm{x}
\end{aligned}
$$

\section{b. Leaving flow}

Leaving flow adalah jumlah dari yang memiliki arah menjauh dari titik a. dan hal ini merupakan pengukuran outrangking. Adapun persamaannya:

$$
\phi^{-}=\frac{1}{n-1} \sum p(a, x)
$$

Ket : $\emptyset^{-}=$leaving flow

$\mathrm{n}=$ jumlah alternatif

$\mathrm{p}(\mathrm{a}, \mathrm{x})=$ preferensi a terhadap $\mathrm{x}$ c. Net Flow

Sehingga pertimbangan dalam penentuan $\mathrm{Net}$ flow diperoleh dengan persamaan :

$$
\emptyset=\phi^{+}(a)-\phi^{-}(a)
$$

$$
\text { Ket: } \begin{aligned}
\emptyset & =\text { net flow } \\
\emptyset^{+} & =\text {entering flow } \\
\emptyset^{-} & =\text {leaving flow }
\end{aligned}
$$

Semakin besar nilai Entering flow dan semakin kecil Leaving flow maka alternatif tersebut memiliki kemungkinan dipilih yang semakin besar. Perangkingan (daDainn PROMETHEE I dilakukan secara parsial, yaitu didasarkan pada nilai Entering flow dan Leaving flow. Sedangkan PROMETHEE II termasuk perangkingan komplek karena didasarkan pada nilai Net flow masingmasing alternatif yaitu alternatif dengan nilai $\mathrm{Net}$ flow lebih tinggi menempati satu rangking yang lebih baik.

\subsection{Analisa Kredit}

Kredit adalah penyediaan uang atau tagihan yang dapat dipersamakan dengan itu, berdasarkan persetujuan atau kesepakatan pinjam-meminjam antara bank dengan pihak lain yang mewajibkan pihak peminjam untuk melunasi utangnya setelah jangka waktu tertentu dengan pemberian bunga (UU NO.10 TAHUN 1998).

Bank adalah badan usaha yang menghimpun dana dari masyarakat dalam bentuk simpanan dan menyalurkannya kepada masyarakat dalam bentuk kredit dan atau bentuk bentuk lainnya dalam rangka meningkatkan taraf hidup rakyat banyak (UU No.10 Tahun 1998).

Penerima kredit adalah siapa saja yang mendapat kredit dari bank dan wajib mengembalikannya setelah jangka waktu tertentu. Istilah siapa saja di sini mempunyai arti luas yang meliputi perseorangan dan badan usaha. Bank-bank dalam menilai suatu permintaan berpedoman kepada faktor-faktor antara lain:

a) Watak (character)

b) Kemampuan (capacity)

c) Modal (capital)

d) Jaminan (collateral) dan

e) Kondisi ekonomi (condition of economy).

Kelima syarat-syarat itu merupakan ukuran kemampuan penerima kredit untuk mengembalikan pinjamannya.

Ke-lima faktor diatas dijadikan pedoman semua bank dengan mengembangkan menjadi beberapa kreteria, termasuk BPR BMD Syariah seperti terlihat pada Tabel 2 dibawah ini. 
Tabel 2. Daftar Kriteria

\begin{tabular}{lll}
\hline Kd & no & \multicolumn{1}{c}{ Kriteria } \\
\hline f1 & 1 & Kelengkapan dokumen syarat \\
f2 & 2 & Pekerjaan \\
f3 & 3 & penghasilan / bulan \\
f4 & 4 & pengeluaran / bulan \\
f5 & 5 & Tembusan dokumen \\
f6 & 6 & Referensi \\
f7 & 7 & Historis nasabah \\
f8 & 8 & angsuran lain-lain \\
f9 & 9 & Jaminan kredit \\
f10 & 10 & Tujuan kredit \\
f11 & 11 & Besar kredit \\
f12 & 12 & Suku bunga \\
f13 & 13 & Masa kredit \\
f14 & 14 & Harga jaminan \\
f15 & 15 & Rekening listrik \\
f16 & 16 & Rekening PBB \\
f17 & 17 & Usia calon nasabah \\
\hline
\end{tabular}

Untuk itu diperlukan sebuah manajemen kredit yang bisa membantu menganalisa kelayakan pemberian kredit kepada nasabah mengingat pentingnya analisa kredit.

\section{Metodologi}

\subsection{Bahan}

Bahan yang dibutuhkan dalam penelitian ini adalah data kreteria kriteria apa saja yang dibutuhkan pihak Bank untuk memberi kredit kepada nasabah. Setiap bank memiliki kreteria yang berbeda beda, hal ini tergantung dari kebijakan pengambil keputusan di Bank tersebut. Maka dari itu penelitian ini mengambil studi di BPR BMD Syariah Madiun agar lebih terfokus. Penelitian ini dapat dikembangkan sesuai kebutuhan pihak pengguna. Data yang didapatkan seperti pada Tabel 2.

\subsection{Alat penelitian.}

Bahan penelitian yang berkaitan dengan kebutuhan umum mengetahui spesifikasi kebutuhan untuk sistem. Spesifikasi kebutuhan umum melibatkan perangkat keras, dan perangkat lunak.

a. Perangkat Keras

Perangkat keras merupakan salah satu hal yang harus diperhatikan, karena tanpa perangkat keras yang memenuhi syarat, aplikasi yang akan dibangun tidak akan bisa berjalan dengan baik. Berikut spesifikasi perangkat keras sesuai dengan asset yang tersedia :

$\begin{array}{ll}\text { Processor } & : \text { Dual Core } \\ \text { Memory } & : 128 \mathrm{Mb} \\ \text { Harddisk } & : 320 \mathrm{~GB}\end{array}$

b. Perangkat Lunak

Kebutuhan perangkat lunak merupakan faktorfaktor yang dibutuhkan untuk menunjang pembuatan aplikasi perangkat lunak itu sendiri, diantaranya adalah sebagai berikut :

\author{
Sistem Operasi : Microsoft Windows 7 \\ Database : MySQL 5.0.67 \\ Aplikasi Builder : PhP Designer 6.5.2 \\ Web Server : Apache2 dan PHP 5.2.6 \\ Web Browser : Mozilla Firefox v.3.0.6 dan \\ IE 7 serta dilengkapi \\ dengan flash plugin dan \\ javascript enable.
}

\section{Hasil dan Pembahasan}

Hasil penelitian yang telah dilakukan dengan menerapkan metode PROMETHEE untuk menentukan prioritas pemberian kredit menampilkan laporan perankingan data nasabah mulai ranking pertama sampai terakhir. Dengan laporan itu pihak pengambil keputusan bisa mengambil kebijakan sampai ranking ke berapa yang akan mendapatkan kredit dengan memperhatikan keseimbangan neraca keuangan bankImplementasi sistem dilakukan sesuai dengan perancangan pengembangan sistem informasi untuk menentukan pemberian kredit dengan metode PROMETHEE yang akan menghasilkan perankingan nasabah yang mengajukan kredit berdasarkan survey dari AO dalam bentuk DFD. Implementasi sistem yang akan dibahas adalah mengenai gambaran desain halaman (user interface) dan form-form yang terdapat dalam sistem informasi ini dengan tujuan agar mudah dimengerti dan dipelajari oleh pengguna meliputi :

a. Input

Media input dirancang dan dibuat untuk memasukan data data master yang akan digunakan untuk proses perankingan nasabah yang mengajukan kredit. Media input pada sistem informasi ini terdiri dari : input login, input user manager, input account office (AO), input pendaftaran nasabah, input survey, dan input kriteria.

b. Proses

Untuk melakukan proses melibatkan dari beberapa data master dan akan menghasilkan output yang diharapkan sesuai dengan kerangka sistem yang dibangun. Media proses pada sistem ini terdiri dari : proses data nasabah, proses data survey, dan proses perankingan.

c. Output

Output adalah hasil dari proses perhitungan dengan menggunakan metode PROMETHEE dalam pengembangan ke sebuah sistem informasi yang sudah ditentukan didalam perancangannya. Yang medianya meliputi : inisialisasi, indeks preferensi, ranking, dan cetak.

Penelitian ini membandingkan perhitungan manual yang selama ini dilakukan oleh pihak bank dengan perhitungan menggunakan sistem informasi dengan metode PROMETHEE yang ditunjukan pada Tabel 3. 
Tabel 3. Perbandingan perankingan perhitungan manual dengan metode PROMETHEE

\begin{tabular}{|c|c|c|c|}
\hline \multicolumn{3}{|c|}{ MANUAL } & \multirow{2}{*}{$\begin{array}{l}\text { PROMETHEE } \\
\text { ranking }\end{array}$} \\
\hline Nama & nilai & Ranking & \\
\hline A & 48 & 1 & 1 \\
\hline B & 46 & 5 & 3 \\
\hline $\mathrm{C}$ & 48 & 2 & 2 \\
\hline D & 44 & 6 & 5 \\
\hline E & 47 & 3 & 4 \\
\hline $\mathrm{F}$ & 47 & 4 & 6 \\
\hline
\end{tabular}

Data tersebut menggunakan inisial dikarenakan menyangkut etika dan kerahasiaan pihak bank diberi nama dengan inisial huruf A dan seterusnya dari hasil survey dan perankingan manual diperoleh data pad: Nasabah A nilai 48, nasabah B nilai 46, nasabah C nilai 48 , nasabah $\mathrm{D}$ nilai 44 , nasabah $\mathrm{E}$ nilai 47 , nasabah $F$ nilai 47. Dari nilai ke - enam calon nasabah didapatkan ranking sebagai berikut : A ranking $1, \mathrm{~B}$ ranking $5, \mathrm{C}$ ranking $2, \mathrm{D}$ ranking $6, \mathrm{E}$ ranking $3, \mathrm{~F}$ ranking 4 . Dalam perjalanan waktu pembayaran angsuran kredit nasabah $\mathrm{F}$ bermasalah. Dengan menggunakan sistem informasi yang dibangun menghasilkan perankingan sebagai berikut : calon nasabah A ranking 1, C ranking 2, B ranking 3, E ranking 4, D ranking 5, dan $F$ ranking 6, maka dari itu dengan menggunakan sistem informasi untuk menentukan prioritas pemberian kredit dengan metode PROMETHEE ini masalah kredit macet tersebut bisa dihindari.

\section{Kesimpulan}

Pengembangan sistem informasi untuk menentukan prioritas pemberian kredit dengan metode PROMETHEE dapat mengetahui ranking dari calon nasabah yang layak mendapatkan kredit. Sistem informasi yang dibangun ini menghasilkan perankingan dengan urutannya sebagai berikut ini:
Calon nasabah $\mathrm{A}$ ranking 1, $\mathrm{C}$ ranking 2, $\mathrm{B}$ ranking 3 , E ranking 4 , D ranking 5 , dan $\mathrm{F}$ ranking 6 , maka bila dibandingkan yang dengan perankingan selama ini dilakukan pihak bank terjadi perbedaan ranking yang menempatkan calon nasabah $\mathrm{F}$ di ranking 4 yang ternyata dalam pembayaran angsuran kredit terjadi masalah.

\section{Daftar Pustaka}

Alessio, I. and Nemery, P., 2011. Selecting the Best Statistical Distribution With PROMETHEE and GAIA, united Kingdom, 958 - 969.

Amir, A.S., Chaharsooghi, K., Esfahanipour, A., 2005. Decision making in stock trading: An application of PROMETHEE, Tehran, Iran, 673683

Brans, J.P., Vincke, Ph., Mareschal, B., 1996. How to select and how to rank projects: The PROMETHEE method. European Journal of Operational Research, 24, 228-238.

Halouani, N., Chabchoub, J., Martel, J.M., 2007. PROMETHEE-MD-2T method for project selection, a University of Economic Sciences and Management, Sfax, Tunisia, b Laval University, Quebec, Canada, 841-849.

Hu, Y.C. and Chiung, J.C., 2011. A PROMETHEE based classification method using concordance and discordance relations and its application to bankruptcy prediction

Yilmaz, B., Metin, D., 2011. A combined approach for equipment selection: F-PROMETHEE method and zero-one goal programming, Department of Industrial Engineering, Faculty of Engineering, Gazi University, 06570 Maltepe, Ankara, Turkey 